\title{
What use is the Neo-Classical Theory of International Trade?
}

\section{Part II: International Trade without Comparative Advantages ${ }^{1}$}

\section{Sikander Rahim}

\section{A. Summary of Part I}

The first part of this paper showed that the neo-classical theory of international trade leads to conclusions that contradict the facts or leads to no conclusions that can be verified. The version of the theory with two factors and the same production functions in different countries has some appeal because relative abundance of factors or intensities of their use have consistent meaning and make the theory plausible, but it results in the Leontief paradox and factor price equalisation. This appeal is lost when the number of factors is greater than two or production functions are not the same in different countries; relative abundance and intensity can not be consistently ranked or their connections to the pattern of trade is not the simple one of the Heckscher-Ohlin theory. Nor does the theory have much left to say; the kind of verifiable general prediction that was possible with two factors is not possible when the factors are more than two; such conclusions as can, in principle, be drawn are specific to the general equilibrium calculated for a given set of production functions and a given set of countries, with specified factor endowments and consumer preferences.

In practice, not even such specific conclusions can be drawn. No model appears to have been constructed that calculates general equilibrium for a group of countries while deriving incomes from factor prices and allowing for a sufficient number of different goods to be a plausible description of trade as it actually occurs. Trade models with more than two factors always assume that demand for goods is entirely determined by the prices of the goods and neglect the effects of income and, hence, of factor prices. Sometimes consumer preferences are assumed to be homothetic, which makes demand independent of income distribution but does not make the model more realistic.

In the real world countries exchange the same or similar goods. Prima facie this is not compatible with the notion of comparative

\footnotetext{
${ }^{1}$ For brevity the country China is referred to as consisting of three economies, China, Hong Kong and Taiwan, because, although they constitute one country, they are economies run along different lines.
} 
advantages, according to which countries export the goods for which they have comparative advantages and import the ones for which they do not. One way of overcoming the incompatibility is to make the differentiation between goods so fine those countries only exchange goods that are different. Thus, two countries may export small cars to each other, but the differences in the designs of the cars make them different goods. The problem with this is that minor differences, like the shape of the hood, are supposed to be the consequences of the characteristics of each country, e.g. its factor endowments. Because of the absurdities that follow, economists have preferred to avoid this course. Besides, such differentiation ensures that the number of goods to be included in the model will be too great for any possibility of calculating a general equilibrium.

An alternative way proposed by Helpman and Krugman is to assume that the countries that exchange similar goods have the same factor prices, because that permits such trade. With the additional assumption of increasing returns to scale, specialisation occurs in different variants of the same type of goods. The explanation purports to apply to Europe, Japan and North America, but it requires that differences in real or nominal wages between, say, the UK, US and Sweden be negligible, which they are not. Nor does it explain why these economies were able to exchange similar goods in the 1950s, 1960s and 1970s, when Europe's and Japan's wage rates were lower compared to the US than now. And it fails to deal with the cars exported by Mexico and Brazil, the machine tools exported by Taiwan, the computer components exported by Korea, the aircraft exported by Brazil and so on. Finally, a model like this, presented in the abstract, with no attempt to test it or to show how it can be tested, does not qualify as a theory or an explanation.

The neo-classical theory also fails because the concept of a factor is not adequately determined. Firstly, the list of factors is left indeterminate, often as though it were a matter of choice, whereas in a verifiable theory the factors and their characteristics would be expected to be definite, meaning that economists would generally agree on what the factors are that determine international trade. Even the number of factors is treated as a matter of choice.

Secondly, the theory must assume that factors and products are separate, i.e. those factors are not products. If factors can be produced, if capital goods or their stock can be assumed to be factors of production, an inconsistency arises. For, in the standard general equilibrium of the neoclassical theory of international trade, prices are determined by endowments and consumer preferences and are, therefore, unrelated to the past costs of producing those factors. One way the inconsistency can be removed is by 
going from one-period to inter-temporal equilibrium, with the addition of equations to make the earnings from capital goods consistent with the costs of producing them. Such models have been devised for the closed economy, though, in view of their assumptions regarding the foresight of economic agents and the prevalence of forward markets, few consider them to be descriptions of reality or guides to policy. No model of inter-temporal equilibrium with several countries and heterogeneous capital goods has yet been attempted. Moreover, the chances are remote that such a model will be devised that is elaborate enough to be realistic and that passes empirical testing. But if one were to be devised, it would yield a different pattern of trade to that of the present-day one-period models by allowing the trade in capital goods.

Alternatively, capital goods can be assumed to have properties that prevent the inconsistency from arising in the one-period equilibrium. In the neo-classical theory this is done by treating capital as one or several malleable substances whose quantities can be measured independently of factor prices and the place of production. By this means prices are determined by the usual marginal relations of production functions and consumer preferences of neo-classical economics, all of which can be satisfied in the one-period equilibrium. But, although presented as a heuristic device, as a parable, paradigm, pragmatic simplification of complex reality and so on, the assumption has to be taken literally. For, if the assumption is not literally true and countries do not have the same factor prices, the price of any capital good depends on where it is produced. Then, regardless of how the quantity of capital embodied in a capital good or set of capital goods is measured, the quantity of the capital goods differs from their value, and the inconsistency of the previous paragraph returns.

Haberler's representation of trade, in which an economy is represented simply as a convex production set, shows why the shortcomings of the neo-classical theory are inescapable. It assumes that both short term and long term rates of transformation are given by movements along the production frontier. But, if capital goods are not malleable, these two rates are not equal. Then the prices of capital goods depend on where they are produced and the production frontiers depend on prices. The problems of the Heckscher-Ohlin theory are, moreover, magnified in it. Being more general than the Heckscher-Ohlin theory, because it abstracts from the relations between the production of individual goods and the means of production, the Haberler representation has even less to say about trade; the only conclusion that can be drawn from it, without the addition of special assumptions, is that free trade is best: the general problem of neo-classical trade theory -- policy prescriptions from an unverifiable theory. 
If the neo-classical theory of trade, whether the Heckscher-Ohlin theory or the Haberler representation, does not hold, the notion of comparative advantages, according to which the prices and allocations of factors in countries adjust to yield an equilibrium, can not hold either. For the only other form of comparative advantages is the theory of Ricardo, according to which costs and output are proportional to the inputs of labour, and this is not accepted theory.

\section{B. Bensusan-Butt's Model}

Trade theory has been so completely associated with comparative advantages since Ricardo first formulated the notion that it may seem impossible for it to be otherwise. Yet models and theories of trade without comparative advantages can be devised easily enough. This was done already in 1954 by Bensusan-Butt. The paper attracted much attention at the time, but was ignored after that and forgotten. Already Chipman's survey of trade theory, which appeared in 1965-66, makes no reference to it. Nor does Bhagwati's survey that appeared in 1968. None of the standard textbooks on international economics refers to it and their authors are most likely unaware of it.

In Bensusan-Butt's model the same techniques of production are available to all countries and each good can be produced by unassisted workers (manually) or by workers operating machines, which can also be produced in both these ways. The output per worker is higher with machines than without. Bensusan-Butt discusses what happens when two countries, A and B, have given workforces fully employed in manual production with the same wage rate and one country, A, begins to produce machines. Entrepreneurs in A first employ machines to produce the good that gives the highest return, and manual production of that good in $\mathrm{A}$ is progressively displaced by machines until none is left. At that point trade with B starts. There was no reason to trade before, but now B's manual production of that good is displaced in the same way as was A's. Once mechanisation is completed for that good, it proceeds to the good offering the next highest return on investment, which means the price of the first good falls to yield the same return. Employment remains full because of the rise in incomes and the demand for machines, while trade balances because B exports manually produced goods to meet A's growing demand for them and imports machine made goods.

Bensusan-Butt's model differs from comparative advantages in several respects; the nominal wage is given and trade occurs because of differences in mechanisation; trade does not occur if the two countries mechanise in step; the gains to workers occur as mechanisation progresses and prices fall; 
entrepreneurs in one country benefit if the other country is behind in mechanisation, because they can increase the scale of their production, and, hence, the sum of their profits, by displacing manual production in the other country, but they lose as the rate of return falls. The whole is a process through time, not a one-period equilibrium. None of these differences is a consequence of 'rigidities' in the nature of capital in Bensusan-Butt's mode1; the model assumes that each machine can be used to produce any type of good and the model presented below in the present paper puts no limit to the number of techniques of production. The reason for the differences is the assumption in the neo-classical theory that capital can be treated as a quantity independently of prices, wages and rates of return, an assumption whose illegitimacy and consequences only began to become clear with the publication of Joan Robinson's paper 'The Production Function and the Theory of Capital' in 1954.

\section{A Model of Trade and Development}

The model of the present article follows that of Bensusan-Butt in assuming that nominal wages are given, that the same techniques of production are available to all countries and that goods can be produced by workers using machines, which are also produced goods. But it is intended to examine two questions that Bensusan-Butt did not discuss; what happens when one country is a developing country with a low wage and the other a developed country with a high wage, and what are the effects of trade barriers, in particular of tariffs?

When a country is developed, i.e. produces every type of manufactured good that it uses, the prices of all goods that are actually produced are given by the costs of production there, excepting those that are produced by the developing country and used entirely by it or which have no substitute in the developed country, e.g. a primary product only produced in the developing country. The developed country, denoted by $\mathrm{A}$, is assumed to be the price setter and the developing country, $\mathrm{B}$, the price taker. The people of $A$ and $B$ are assumed to consume the same types of goods.

Since A's nominal wage is assumed to be higher than B's and prices of goods are assumed to be the same in both countries when trade is free, once entrepreneurs in B start mechanising production, they obtain rates of return higher than that prevailing in A. This is true even if they choose an activity that occurs in A (produce the same good with the same type of machine), but they may be able to obtain a still higher rate of return if they use a different type of machine to take advantage of B's lower wage. The goods that are produced at lower cost in A than in B are those for which the higher rate of return in $B$ more than offsets the lower wage. The highest rate of return 
obtainable in B may come from producing a consumption good and importing the machines to make it, but it might equally come from producing a certain type of machine for export and importing the machines to make it, or from importing machines to make machines to make consumption goods. In the first case producing the consumption goods can be loosely said to be less capital intensive than producing capital goods, whereas in the second the capital goods are the less capital intensive to produce. In the last case the production of consumption goods in B with machines produced in B is less capital intensive than producing the consumption good in B with machines produced at A's costs.

Assuming that the highest rate of return in B is obtained by making a consumption good using imported machines, once B produces enough of that good to satisfy domestic demand at the given prices, it begins to export to A. Then, if A imposes tariffs, it lowers the price B obtains for its exports and, hence, the rate of return obtainable in $\mathrm{B}$ and, if the tariffs exceed a certain level, the rate of return from making consumption goods there falls below that obtained from making machines. For, if the rate of return is lowered to that of $\mathrm{A}$, machines are cheaper to produce in $\mathrm{B}$ because of the lower wage. So above that rate there is a rate that exactly offsets B's lower wage so that machines cost the same to produce there as in A and, corresponding to it, is a tariff level. A higher tariff gives a lower rate of return in B and makes machines cheaper to make there. Consequently, a developing country facing trade restrictions may find it obtains a higher rate of return on investment by producing its own capital goods and that the capital or labour intensity of various branches of production depend on tariffs, wages and where the means of production are made. The belief that textile production, for instance, is labour intensive and hence suited to low wage countries ignores the effects on prices of the developed countries' trade restrictions.

The model that follows is intended to demonstrate the consistency of the reasoning of the two preceding paragraphs, but it also serves to bring to light some phenomena that are not obvious when the reasoning is purely verbal. To begin the model assumes two consumption goods and is confined to examining how and where these goods are produced and what effects tariffs may have. The extension to more consumption goods is straightforward and is discussed briefly.

\section{A Model of Trade and Development}

\section{One technique of mechanised production}

The argument made above verbally about the tariffs and the choice of sectors can be presented by a simple model. A homogeneous 
consumption good, to be called cloth, is assumed to be produced by a machine, to be called a b-machine, one man operating one b-machine produces one unit of cloth per period. b-machines are produced by kmachines, one man operating one k-machine producing one b-machine per period. k-machines can also produce k-machines, one man operating one kmachine producing $\mu \mathrm{k}$-machines per period.

Denoting the nominal wage in country $\mathrm{A}$ by $\mathrm{W}$ and the rate of return by $\mathrm{R}$ and assuming that machines last forever:

$$
\begin{aligned}
& \mathrm{W}+\mathrm{R} \cdot \mathrm{B}=\mathrm{P} \\
& \mathrm{W}+\mathrm{R} \cdot \mathrm{K}=\mathrm{B} \\
& \mathrm{W}+\mathrm{R} \cdot \mathrm{K}=\mu . \mathrm{K} .
\end{aligned}
$$

where $\mathrm{P}, \mathrm{B}$ and $\mathrm{K}$ are the prices of cloth, b-machines and $\mathrm{k}$-machines respectively.

In the case that the highest rate of return obtainable in country B is obtained from producing cloth with imported b-machines, denoting the nominal wage in country $B$ by $w$ and the rate of return by $r$, and assuming that, given the prices:

$$
\begin{aligned}
& \mathrm{w}+\mathrm{r} . \mathrm{B}=\mathrm{P} \\
& \mathrm{w}+\mathrm{r} . \mathrm{K}>\mathrm{B} \\
& \mathrm{w}+\mathrm{r} . \mathrm{K}>\mu . \mathrm{K} .
\end{aligned}
$$

In this case, denoting by $\mathrm{r}^{\prime}$ the rate of return that country $\mathrm{B}$ would get if it imported k-machines, made b-machines and with these made cloth,

Then:

$$
\begin{aligned}
& w+r^{\prime} .\left(w+r^{\prime} . K\right)=P . \quad r>r^{\prime} . \\
& w+r .(w+r . K)>P,
\end{aligned}
$$

Which is to say that country B gets a lower rate of return if it makes its own machines.

If country A applies an ad valorem tariff, $\mathrm{t}$, on imports of cloth, the price country $B$ gets for cloth is $P /(1+t)$.

Then:

$$
\begin{aligned}
& \mathrm{w}+\mathrm{r} \cdot \mathrm{B}=\mathrm{P} /(1+\mathrm{t}) \\
& \mathrm{w}+\mathrm{r}^{\prime} \cdot\left(\mathrm{w}+\mathrm{r}^{\prime} \cdot \mathrm{K}\right)=\mathrm{P} /(1+\mathrm{t}) .
\end{aligned}
$$

But, $\quad w+R \cdot K<W+R \cdot K=B$. That is, since country $B$ has a lower wage, $\mathrm{b}$-machines are cheaper to produce there if the rate of return there is the same as in A. So, if A's tariff is raised so high that: 
then

$$
\begin{aligned}
& \mathrm{P} /(1+\mathrm{t})=\mathrm{w}+\mathrm{R} \cdot \mathrm{B}, \quad \text { that is, such that } \mathrm{r}=\mathrm{R}, \\
& \mathrm{w}+\mathrm{R} .(\mathrm{w}+\mathrm{R} \cdot \mathrm{K})<\mathrm{P} /(1+\mathrm{t}) .
\end{aligned}
$$

At this tariff, $r^{\prime}>R$. Then there is a $t^{\prime}>0$ such that, $r^{\prime}>r$ if $t>t^{\prime}$. This means that, if tariffs are raised high enough, country $B$ obtains a higher return from producing its own machines for making cloth. Moreover, if country B makes its own k-machines, it is assured a positive rate of return, r", given by:

$$
\mathrm{w}+\mathrm{r}^{\prime \prime} . \mathrm{K}=\mu . \mathrm{K}
$$

and this occurs for $\mathrm{t}<\mathrm{P} / \mathrm{w}-1$, that is at a level for country A's tariff that still allows a positive rate of return on country B's exports.

The conclusion, obvious to common sense, is that the greater the protection by developed countries, the more self-reliant developing countries ought to be.

\section{Several techniques of mechanised production}

The model can be elaborated to include choice of techniques and depreciation. The consumption good, cloth, remains the same, but bmachines are of various types, the type being denoted by a suffix. A $b_{y}$ machine is manned by one worker and has an output of $\alpha_{y}$ of units of cloth per period. The number of $b_{y}$-machines produced by a $k_{x}$-machine and $a$ worker is $\beta_{x y}$. For simplicity, rather than having various types of $k$-machines make various types of $\mathrm{k}$-machines, $\mathrm{k}$-machines are assumed to be made by $\mathrm{m}$-machines, of which there is only one type. An m-machine is manned by one worker and the number of $k_{x}$-machines it can produce per period is $\kappa_{x}$ and the number of $\mathrm{m}$-machines it can produce instead is $\mu$.

At the start the developed country, A, makes cloth for its own consumption and that of $\mathrm{B}$. It also produces all the machines it needs to make cloth and to replace machines as they wear out. B's labour is fully employed in the manual production of corn, which is also produced in A with the aid of machines. Further details of corn production are not needed, it simply represents the activity of the population of $B$ before industrialisation begins, including the export that allows the import of cloth, and is convenient as a numeraire when one is needed.

The wage and rate of return in $\mathrm{A}$ are denoted, as before, by $\mathrm{W}$ and $\mathrm{R}$. Cloth is made with $\mathrm{b}_{\mathrm{t}}$-machines, which are made by $\mathrm{k}_{\mathrm{s}}$-machines. Any other combination results either in a higher price of cloth relative to $\mathrm{W}$ or a lower R. Each machine is assumed to last T periods and then to collapse, 
when it becomes valueless and is disposed of costlessly. The prices in A are given by the following equations:

$$
\begin{aligned}
& \mathrm{W}+(1+\mathrm{R}) \cdot \mathrm{M}_{1}=\mu \cdot \mathrm{M}_{1}+\mathrm{M}_{2}, \\
& \mathrm{~W}+(1+\mathrm{R}) \cdot \mathrm{M}_{\mathrm{p}}=\mu \cdot \mathrm{M}_{\mathrm{p}}+\mathrm{M}_{\mathrm{p}+1}, \\
& \mathrm{~W}+(1+\mathrm{R}) \cdot \mathrm{M}_{\mathrm{T}}=\mu \cdot \mathrm{M}_{1} \\
& \mathrm{~W}+(1+\mathrm{R}) \cdot \mathrm{M}_{1}=\kappa_{\mathrm{s}} \cdot \mathrm{K}_{\mathrm{s} 1}+\mathrm{M}_{2}, \\
& \mathrm{~W}+(1+\mathrm{R}) \cdot \mathrm{M}_{\mathrm{p}}=\kappa_{\mathrm{s}} \cdot \mathrm{K}_{\mathrm{s} 1}+\mathrm{M}_{\mathrm{p}+1} \\
& \mathrm{~W}+(1+\mathrm{R}) \cdot \mathrm{M}_{\mathrm{T}}=\kappa_{\mathrm{s}} \cdot \mathrm{K}_{\mathrm{s} 1} \\
& \mathrm{~W}+(1+\mathrm{R}) \cdot \mathrm{K}_{\mathrm{s} 1}=\beta_{\mathrm{st}} \cdot \mathrm{B}_{\mathrm{t} 1}+\mathrm{K}_{\mathrm{s} 2}, \\
& \mathrm{~W}+(1+\mathrm{R}) \cdot \mathrm{K}_{\mathrm{sp}}=\beta_{\mathrm{st}} \cdot \mathrm{B}_{\mathrm{t} 1}+\mathrm{K}_{\mathrm{s} 2 \mathrm{p}+1}, \\
& \mathrm{~W}+(1+\mathrm{R}) \cdot \mathrm{K}_{\mathrm{sT}}=\beta_{\mathrm{st}} \cdot \mathrm{B}_{\mathrm{t} 1}, \\
& \mathrm{~W}+(1+\mathrm{R}) \cdot \mathrm{B}_{\mathrm{t} 1}=\alpha_{\mathrm{t}} \cdot \mathrm{P}+\mathrm{B}_{\mathrm{t} 2}, \\
& \mathrm{~W}+(1+\mathrm{R}) \cdot \mathrm{B}_{\mathrm{tp}}=\alpha_{\mathrm{t}} \cdot \mathrm{P}+\mathrm{B}_{\mathrm{tp}+1}, \\
& \mathrm{~W}+(1+\mathrm{R}) \cdot \mathrm{B}_{\mathrm{tT}}=\alpha_{\mathrm{t}} \cdot \mathrm{P} \cdot
\end{aligned}
$$

Here $B_{t p}, K_{s p}$ and $M_{p}$ denote the prices of the corresponding machines in their $\mathrm{p}^{\text {th }}$ periods and $\mathrm{P}$ is the price of cloth. These equations also imply that entrepreneurs are indifferent between using an m-machine of a given age for producing $\mathrm{k}$-machines or $\mathrm{m}$-machines.

Omitting the age suffix, the equations for new machines and cloth can be summarised as:

$$
\begin{array}{ll}
1 . \mathrm{a} & \mu \cdot \mathrm{M}=\mathrm{W}+\mathrm{h}(\mathrm{R}) \cdot \mathrm{M}, \\
1 . \mathrm{b} & \kappa_{\mathrm{s}} \cdot \mathrm{K}_{\mathrm{s}}=\mathrm{W}+\mathrm{h}(\mathrm{R}) \cdot \mathrm{M}, \\
2 . \mathrm{a} & \beta_{\mathrm{st}} \cdot \mathrm{B}_{\mathrm{t}}=\mathrm{W}+\mathrm{h}(\mathrm{R}) \cdot \mathrm{K}_{\mathrm{s}}, \\
2 . \mathrm{b} & \alpha_{\mathrm{t}} \cdot \mathrm{P}=\mathrm{W}+\mathrm{h}(\mathrm{R}) \cdot \mathrm{B}_{\mathrm{t}} ;
\end{array}
$$

where $h(R)=R \cdot(1+R)^{T} /\left[(1+R)^{T}-1\right]$, which is monotonically increasing if $\mathrm{R}>0$.

When entrepreneurs in B start to invest in machines they choose those that yield the highest return. For the present the prices are taken as given, the effects of B's investment and production on them are taken up later. This allows the main point to be stated without complications that obscure the argument and do not change the conclusions.

Several techniques of mechanised production: free trade.

Let the highest rate of return obtainable in $B$ come from importing $b_{x}-$ machines made in $\mathrm{A}$ with $\mathrm{k}_{\mathrm{v}}$-machines and producing cloth. Then: 
160 The Lahore Journal of Economics, Vol.4, No.2

$$
\begin{array}{ll} 
& \kappa_{v} \cdot K_{v}=W+h(R) \cdot M \\
3 . a & \beta_{v x} \cdot B_{x}=W+h(R) \cdot K_{v}, \\
3 . b & \alpha_{x} \cdot P=w+h(r) \cdot B_{x} .
\end{array}
$$

Since $\mathbf{w}<\mathrm{W}, \mathbf{r}>\mathrm{R}$.

By hypothesis, on the assumption that $b_{t}$-machines and $b_{x}$-machines are different, making $b_{t}$-machines in $B$ or making them in $A$ and operating them in $B$ yield lower returns. For the same reason, $b_{x}$-machines are not operated in A. Then:

$$
\begin{array}{ll}
\text { 4.a } & \mathrm{w}+\mathrm{h}(\mathrm{r}) \cdot \mathrm{K}_{\mathrm{s}}>\beta_{\mathrm{st}} \cdot \mathrm{B}_{\mathrm{t}} \\
\text { 4.b } & \mathrm{w}+\mathrm{h}(\mathrm{r}) \cdot \mathrm{B}_{\mathrm{t}} \cdot>\alpha_{\mathrm{t}} \cdot \mathrm{P} \\
& \\
\text { 5.a } & \mathrm{w}+\mathrm{h}(\mathrm{r}) \cdot \mathrm{K}_{\mathrm{v}}>\beta_{\mathrm{vx}} \cdot \mathrm{B}_{\mathrm{x}} \\
\text { 5.b } & \mathrm{W}+\mathrm{h}(\mathrm{R}) \cdot \mathrm{B}_{\mathrm{x}} \cdot>\alpha_{\mathrm{x}} \cdot \mathrm{P}
\end{array}
$$

From these follow: $B_{x}<B_{t}, K_{s}, K_{v}$, which is to say that, because its wage is lower, country $B$ uses less capital per head than A.

If, instead, the highest rate of return obtainable in B were to come from importing $\mathrm{k}_{\mathrm{y}}$-machines and making and operating $\mathrm{b}_{\mathrm{z}}$-machines there, $\mathrm{B}_{\mathrm{z}}$ and $r$ would be defined by:

$$
\begin{array}{ll}
\text { 6.a } & w+h(r) \cdot K_{y}=\beta_{y z} \cdot B_{z} \\
\text { 6.b } & w+h(r) \cdot B_{z}=\alpha_{z} \cdot P .
\end{array}
$$

3.a ceases to hold and 6.b has the same form as 3.b. By hypothesis, $b_{z}-$ machines cost more to produce or to operate in $\mathrm{A}$, so:

$$
\begin{array}{ll}
\text { 7.a } & W+h(R) \cdot K_{y}>\beta_{y z} \cdot B_{x z} \\
\text { 7.b } & W+h(R) \cdot B_{z}>\alpha_{z} \cdot P .
\end{array}
$$

Then $B_{z}, K_{y}<B_{t}, K_{s}$ and $\alpha_{z}<\alpha_{t}$. Again, $B$ uses less capital per head and has a lower output per head than $\mathrm{A}$.

At some moment entrepreneurs in B begin to invest and they choose the activity that gives the highest rate of return. In the following discussion of industrialisation in $\mathrm{B}$ the highest rate of return obtainable in $\mathrm{B}$ in free trade is assumed to be given by importing $\mathrm{b}_{\mathrm{x}}$ - machines made in $\mathrm{A}$ with $\mathrm{k}_{\mathrm{v}}$ machines and producing cloth.

The effect of the growth of output on prices can be discussed in two ways. One is to assume that entrepreneurs and workers in both countries 
act with perfect foresight and move freely from one activity to another. Then, as B's output of cloth increases, A's entrepreneurs withdraw from the production of cloth. If the growth of B's output is fast enough for some $b_{t}$ machines in $\mathrm{A}$ to be scrapped before they cease to be usable, they are amortised faster to yield the same rate of return. Similarly, $\mathrm{k}_{\mathrm{s}}$-machines will be scrapped early and amortised faster if they are not fully used for producing $b_{x}-$ machines for export. Hence, A's entrepreneurs reduce their own production of cloth in such a manner as to allow prices to rise by enough to obtain the same rates of return as before on investments that last a shorter time. The price of cloth rises and perhaps so does the price of $b_{t}$ machines. The real wage falls.

In this equilibrium expectations are satisfied, but prices are complicated to calculate. They depend on the rate of investment in B and the relative sizes of A's and B's cloth producing sectors, and then the possibility arises that, because of the price movements, other types of machines become more profitable in either country. Explicit formulae for prices become unmanageably complicated, if not impossible. These complications can be avoided by assuming, as did Bensusan-Butt, that machines last forever and can be used at any time to produce any good and are only of one type. But the existence of amortisation, the dependence of the length of use of an investment on growth and the choice of techniques have effects worth discussing. Nor are explicit formulae needed, the prices and rates of return given by equations 1-4 are adequate reference points for the discussion that follows, and will, for the most part, be used as such.

The second way to discuss the growth of B's output of cloth is to assume that A's entrepreneurs try to compete to keep their markets for cloth and are forced to cut their production because they can always be undercut. The prices of cloth can vary anywhere between the level that just covers the wage cost in A and that, discussed above, given by perfect foresight, and the returns are accordingly below what those obtained with perfect foresight. The real wage may rise.

Perfect foresight and fulfilled expectations are not normally to be expected in the real world, but are interesting because they show, firstly, that full employment and balanced trade can be maintained and, secondly, how the likely behaviour of entrepreneurs can cause losses, unemployment and trade imbalances. In $\mathrm{B}$ workers move from producing corn to producing cloth; in A workers are displaced from the production of cloth and from the production of $\mathrm{k}_{\mathrm{s}}$-machines and $\mathrm{b}_{\mathrm{t}}$-machines for use in $\mathrm{A}$ to the production of $\mathrm{k}_{\mathrm{v}}$-machines, $\mathrm{b}_{\mathrm{x}}$-machines and corn. The number of $\mathrm{m}$-machines and their use may also change. The reduction in B's imports of cloth is balanced by the reduction in its exports of corn, which is a change in its method of 
obtaining cloth, and by its imports of machines, an act of saving. At this stage, since the assumption that the rate of return in $\mathrm{A}$ is unchanged implies that the price of cloth rises, the real wage falls in each country. An alternative, not taken up here, is to assume that, along with perfect foresight and fulfilled expectations, the rate of return declines uniformly in $A$, in which case entrepreneurs lose and workers gain.

Full employment and balanced trade remain possible when foresight is not perfect and expectations can be disappointed, but they are not assured. In $A$ the lower cloth prices deter investment in cloth production and in k-machines by lowering rates of return in these activities, but B's demand for b-machines and the fall in its production of corn stimulate investment for their production in $A$. The net effects on investment, employment and the trade balance depend on how A's entrepreneurs respond to stimulus and deterrent, which depends on what each entrepreneur anticipates will be future investment in B and the reaction of other entrepreneurs. The effect of the stimulus can outweigh that of the deterrent and can cause demand for workers and machines to exceed supply, or can be insufficient and result in deficient demand and unemployment.

Other consumption goods can be assumed to exist and to be made with similar hierarchies of machines. Assuming that consumption goods offer higher rates of return to production in B than machines and assuming, also, full employment and balanced trade, B's entrepreneurs turn to producing the consumption good that offers the next highest rate of return when A's cloth production has been completely displaced, or when the price of cloth falls enough to make the return on producing the other consumption good higher. As B produces a succession of consumption goods in this manner, prices fall and the real wage rises in each country.

\section{Trade and development with tariffs}

In the real world countries restrict imports when domestic production is displaced too fast or too much. Why this happens was discussed in the first part of this article, though the emphasis was on developing countries. Of the several ways of restricting imports, the ad valorem tariff has been the most common and is the simplest to use in the present model. So $\mathrm{A}$ is assumed to impose an ad valorem tariff, $\mathrm{t}$, on imports of cloth. Up to now A and B could be considered to constitute one market for cloth, both countries could have been exporting and importing cloth at the same time. But, with A's tariff, B's consumption of cloth must be met entirely from domestic production before exports to A begin. 
If the price of cloth in country $\mathrm{A}$ is $\mathrm{P}$, the price that country $\mathrm{B}$ receives for the cloth it exports to $\mathrm{A}$ is $\mathrm{P} /(1+\mathrm{t})$. Assuming that prices in $\mathrm{A}$ are given by equations 1 .a to $2 . \mathrm{b}$, the rate of return to producing cloth in $\mathrm{B}$ using $\mathrm{b}_{\mathrm{x}}$-machines is given by:

$$
\mathrm{w}+\mathrm{h}(\mathrm{r}) \cdot \mathrm{B}_{\mathrm{x}}=\alpha_{\mathrm{x}} \cdot \mathrm{P} /(1+\mathrm{t})
$$

If $\mathrm{t}$ is put so high that the price of cloth only covers the wage cost, $\mathrm{w}=$ $\alpha_{x} \cdot P /(1+t)$, country $B$ can only obtain a positive return from importing bmachines by choosing types of these machines which have higher outputs. The higher the tariff, the higher the output of country B's b-machines must be and, therefore, the more capital intensive its cloth production. But, if $t$ is so high that $\mathrm{B}$ can not obtain a positive return using the same b-machines as $\mathrm{A}, \mathrm{w}=\alpha_{\mathrm{t}} \cdot \mathrm{P} /(1+\mathrm{t})$, it can obtain a positive return by importing $\mathrm{k}_{\mathrm{s}}$ machines and making $b_{t}$-machines for export to $A$, because, if $r$ is determined by

Then:

$$
\begin{aligned}
& \mathrm{w}+\mathrm{h}(\mathrm{r}) \cdot \mathrm{K}_{\mathrm{s}}=\beta_{\mathrm{st}} \cdot \mathrm{B}_{\mathrm{t}}=\mathrm{W}+\mathrm{h}(\mathrm{R}) \cdot \mathrm{K}_{\mathrm{s}} \\
& \mathrm{w}<\mathrm{W} \text { implies } \mathrm{r}>\mathrm{R} .
\end{aligned}
$$

This value of $r$ is assured given this level of $t$, but a higher value might be obtained by suitable choice of types of b-machines and k-machines, the highest value being given by:

$$
8 \operatorname{Max}_{\mathrm{mn}}\left\{\mathrm{r} \mid \mathrm{W}+\left[\mathrm{h}(\mathrm{R}) / \beta_{\mathrm{mn}}\right] \cdot\left[\mathrm{w}+\mathrm{h}(\mathrm{r}) \cdot \mathrm{K}_{\mathrm{m}}\right]=\alpha_{\mathrm{n}} \cdot \mathrm{P}\right\}
$$

For some lower values of $t, B$ may obtain its highest rate of return from importing k-machines and making b-machines and using these to make cloth domestically. For, if $t$ is such that B's rate of return on using imported $b_{x}$-machines to make cloth is reduced to the same rate of return, $R$, as in $A$,

$$
\begin{array}{r}
\alpha_{x} \cdot P /(1+t)=w+h(R) \cdot B_{x}=w+\left[h(R) / \beta_{v x}\right] \cdot\left[w+h(R) \cdot K_{v}\right] \\
>w+\left[h(R) / \beta_{v x}\right] \cdot\left[w+h(R) \cdot K_{v}\right],
\end{array}
$$

which says that if $B$, at the same return as in $A$, imports $\mathrm{k}_{\mathrm{v}}$-machines and makes $b_{x}$-machines and uses these to make cloth, its price will be below $\mathrm{P} /(1+\mathrm{t})$, i.e. it can obtain a higher return. Again this return is assured, but, by choosing the types of k-machines and b-machines suitably, it might get a higher rate:

$$
\text { 9. } \operatorname{Max}_{\mathrm{yz}}\left\{\mathrm{r} \mid \mathrm{w}+\left[\mathrm{h}(\mathrm{r}) / \beta_{\mathrm{yz}}\right] \cdot\left[\mathrm{w}+\mathrm{h}(\mathrm{r}) \cdot \mathrm{K}_{\mathrm{y}}\right]=\alpha_{\mathrm{z}} \cdot \mathrm{P} /(1+\mathrm{t})\right\}
$$

and $\mathrm{r}>\mathrm{R}$. 
Since the expression 8 is not a function of $t$ and since $r$ in the expression 9 increases as $t$ decreases, there are values $t^{\prime}$ and $t^{\prime \prime}$ such that the highest value of $r$ obtainable is given by 8 for $t \geq t^{\prime \prime}$ and by 9 for $t^{\prime \prime} \geq t \geq t^{\prime}$. For $\mathrm{t} \leq \mathrm{t}^{\prime}$, B's highest rate of return is obtained from importing b-machines and making cloth.

Then, if $t \geq t^{\prime \prime}, B$ exports b-machines to A, displacing A's production of b-machines and the same sequence follows as was described for cloth under free trade and, in the same way, it either ends when A produces no more b-machines, whereupon B starts exporting some other good, or when $A$ imposes a high enough tariff on imports of $b$-machines. In the latter case $\mathrm{B}$ obtains $\mathrm{m}$-machines from $\mathrm{A}$ and exports $\mathrm{k}$-machines and, if $\mathrm{A}$ puts a high enough tariff on imports of k-machines, B becomes autarkic.

And, if $\mathrm{t}^{\prime \prime} \geq \mathrm{t} \geq \mathrm{t}^{\prime}, \mathrm{B}$ exports cloth to $\mathrm{A}$, but imports $\mathrm{k}$-machines and makes its own b-machines. As B's exports of cloth grow and continue to displace A's cloth production, A might raise $t$ until $t \geq t$ ", whereupon $B$ starts exporting b-machines, as in the preceding paragraph.

\section{E. LESSONS FROM THE MODEL}

\section{Absence of Capital Goods Industries}

The model leads to the conclusion that a developing country whose exports are subject to high tariffs by importing developed countries obtain better rates of return by producing its own capital goods. Yet, in practice, developing countries have rarely reacted to trade barriers in this way and it must be explained why. Pakistan is an extreme example, it specialised in cotton and jute textiles in the 1960s and cotton yarn, cloth and apparel remain its main manufactured exports. These are probably the products that have long been subject to the severest trade restrictions by the developed countries, mostly in violation of the spirit and letter of the General Agreement on Tariffs and Trade. The developed countries restricted imports in the 1950s individually but imposed the restrictions as a group in the Short Term Arrangement of 1960, which, after repeated assurances that it was temporary, became the Long Term Arrangement, which, despite promises that it would be confined to cotton goods, became the Multi-Fibre Arrangement, which is now being gradually eliminated. Yet Pakistan has never developed a noteworthy capital goods industry.

\section{Education and training}

Several explanations can be given for why developing countries do not take the next step of producing their own capital goods. Part of any 
cogent explanation is that these countries nearly always lack the engineering and scientific skills needed. Industrial plant and machinery normally require more engineering and scientific capabilities to manufacture than do producing most textiles, assembling appare1, soldering circuit boards and the many other simple activities in which low wage countries are supposed to have comparative advantages, and these capabilities are lacking because developing countries do not provide enough education and training. (Moreover, many of the ablest scientists and engineers they do produce emigrate to the developing countries.)

The production of these technical capabilities is an investment with a cost, just as the production of machines, except that it is embodied in people. These people are needed for the production of industrial plant and machinery, or any other goods, as much as the plant and machinery being used in that production. Economists sometimes recognise this by classifying such capabilities as a factor separate to labour, capital and land and one with which the developed countries are relatively well endowed. They thereby make the same mistake as with investment in machines, that of ignoring the cost of producing these capabilities. Even if developed countries are relatively well endowed with these skills, they have had to produce them at a cost (except for immigrants) and, by the same reasoning as for capital goods, the developing countries should be able to produce the same skills at lower costs or at least at higher rates of return.

Few developing countries have systematically attempted to produce the scientists and engineers they need and only a sketchy explanation can be offered here. Ultimately, the reason is the peculiarity of education and training as an investment, that it is embodied in people. Because of that, the state must supply the greater part, especially in a developing country, and support the private sector in supplying it as well. In Pakistan, more than in most countries, the wealthier segments of the population have, to the extent they deemed education desirable, had their offspring educated abroad and, at least at first, little of this education was in sciences or engineering. Because they could do this, the wealthy had little stake in the national education system, which has, therefore, been given insufficient attention.

In more recent years international organisations, such as the World Bank and the IMF, have emphasised primary and secondary education on the grounds that they reduce poverty, population growth and the disadvantages of women, and at the same time these organisations discourage emphasis on higher education on the grounds that it costs more per student. Obviously primary and secondary education should be given more emphasis than they have been in Pakistan, but so should higher education. Viewed simply as an investment, scientific and engineering education at universities and beyond, 
if properly imparted and used, yield higher economic returns than they do in the developed countries (provided the recipients of the education do not emigrate). Analogously, the ability of primary and secondary education to relieve poverty depends in the long run on how fast national income grows, and so far no economy has developed that neglected higher education.

\section{Infant industries}

But the lack of scientific and engineering skills, though it must be part of any cogent explanation of why capital goods industries in developing countries are so small and backward, cannot be an explanation by itself. For, if entrepreneurs had wished to invest in capital goods industries, governments would normally have obliged them by providing or helping them provide the necessary higher education. If entrepreneurs have, instead, preferred to invest in technically simple consumer goods industries, it is because they were deterred from capital goods by considerations in addition to the lack of scientific and engineering skills.

The main explanation is that the more complex an industry is technically, the more it must be nurtured as an infant industry. A factory

does not normally produce at maximum efficiency as soon as it is set up. If it is part of a larger enterprise which can supply it personnel of the required skill and experience, it can be expected to be close to efficient operation in a couple of years, after an investment has been made in the training of the workforce. Thus, when Toyota sets up a new factory in the UK, it invests the time of its own Japanese personnel in training the British workforce and in overcoming teething troubles. When a developing country starts a industry new to it, it usually does not have this kind of skilled and experienced personnel. The country may obtain it by attracting a foreign company with the necessary personnel to set up the industry, though this rarely happens in enough industries in a country to make a noticeable difference to the economy, or it may attract nationals working abroad who have the skills and experience, a course that helped Japan in the early stages of its industrialisation. But usually the country must acquire the skills and experience itself.

Hence, if an infant industry that is technically more complex than the simple consumer goods industries to which most developing countries, including Pakistan, are limited is to be nurtured so as to become efficient enough to compete with similar industries in developed countries, not only must the supply of scientific and engineering skills be adequate, but all the workforce (managers, scientists, engineers and shop-floor workers) must be able to acquire the specialised training and experience needed to operate the industrial plant with that level of efficiency. Entrepreneurs must be 
willing and able to cope with the complexity of the industry, despite economic returns that may be low, even negative, for several years, and their financiers must be willing to see them through difficult times with a high risk of failure. Moreover, in the case of capital goods, there must be entrepreneurs or firms willing to use these capital goods when they install new or replace old productive capacity, which means they must not be put at so much of a disadvantage relative to their competitors who obtain better and cheaper capital goods from elsewhere that they can no longer compete.

Since economists and international organisations such as the World Bank, the IMF and the WTO never tire of pointing out that successful infant industries are rare in developing countries, especially Pakistan, what was said in the first part of this article must be repeated: the conclusion to be drawn is, not that infant industries should not be protected, but that making them succeed is difficult. The countries that do not try to make infant industries succeed can expect to remain where they are; the economies that have, since the Second World War, been successful with their infant industries, notably Japan, Korea, Taiwan and Singapore, are no longer counted as underdeveloped. Among the developing economies, that which seems to be developing consistently fastest is China, which is not an open economy and has spent decades developing it own infant industries.

As pointed out in the first part of this article, after its 'Industrial Revolution' had made England the leading industrial economy, every country that has industrialised has done so with the state providing some combination of protection, rewards, punishments and assistance of various kinds. The problem each developing country has to solve is how to design a combination suited to its specific circumstances, along with a set of institutions to administer it so that it does not end in corruption, inefficient enterprises or subservience to special interest. Much can be learnt from the few economies that have successfully industrialised over the last fifty years, notably Japan, Korea and Taiwan, but also from the industrial policies of Germany, the US and other western countries in the nineteenth century.

But designing such a combination has in many ways become harder with time. The successful East Asian economies just mentioned were able to use protection, several kinds of subsidies, state technical expertise, various export incentives and so on, and the western countries, which were their chief markets, tolerated these departures from what was deemed fair trade because these economies were considered to be threatened by communism. That threat has gone and the stake of the developed countries in the development of the developing countries is not the same. Consequently, the developed countries are quick to act against any appearance of infringement of the rules of fair trade as laid down by the WTO, or often by themselves. 
Developing countries must, therefore, devise their own means of fostering their infant capital goods industries. There are no manuals or guidebooks, nor even reliable general analyses of the methods used by the successful economies just mentioned. On the contrary, orthodox economists and institutions, such as the World Bank and the IMF, insist that such methods should not be tried; they argue variously that the methods used by Japan, Korea and Taiwan did not work, that the success of these economies was the result of allowing markets to work, that market distortions were insignificant, that the various measure the authorities in these economies used to influence the behaviour of enterprises did not seriously affect the operation of markets and that the authorities were only deluding themselves when they thought that they did, that the economists of the Anglo-Saxon countries of the West in the 1990s can judge better what went on in Japan in the $1950 \mathrm{~s}$ or $1960 \mathrm{~s}$ than could Japanese officials at the time, that the present developing countries could not possibly do the same things and so on. Certainly, such arguments are easier than solving, country by country, the problems of institutions, laws and procedures, education and training, social structures and the like, all of which are complex, difficult and, yet, inseparable from development.

\section{Unequal exchange}

The consequence for Pakistan of the trade barriers the developed countries imposed on the cotton products it exported was that the income it received, the value added, was low. Estimates of the rates of return for cotton cloth for the early years of Pakistan's textile exports (1954, 1956 and 1959/60), taking only total direct and indirect foreign exchange costs of the current inputs and capital goods, i.e. putting the wage cost at zero and ignoring all non-foreign exchange costs, give 7.4 per cent to 14.8 per cent, depending on the year. If, instead of Pakistan's unit values of exports, UK unit values are used, the rate of return calculated the same way becomes 43.8 per cent. If wages are taken as greater than zero, the rates of return are correspondingly lower, which is to say that these rates of return ignoring wages can be regarded as a measure of the total gain to the economy.

Just taking the ratios of export unit value of textiles less the cost of tradable direct inputs (cotton, dyes, etc.) as a measure of value added and the cost of the tradable investment (e.g. ignoring local construction costs, land, etc.), the associated capital:output ratios range from 5 to 10 . Economists usually consider capital:output ratios of 2-4 to be normal averages for developing economies. Of Kuznets' estimates of incremental capital:output ratios for whole economies, rather than just manufacturing, the highest for high wage countries in the 1950 s was 7.4 for the UK. For 
manufacturing in the US it was only 0.5 . Textiles may have been labour intensive in the developed countries, but the effects of protection on prices made them capital intensive in Pakistan. These poor economic gains were not limited to Pakistan's early efforts to industrialise; the severest restrictions on textile exports came later. The subsequent political, economic and social difficulties are not surprising in the light of this.

When the price-setting country ( $\mathrm{A}$ in the model) imposes a tariff, $\mathrm{t}$, on the import of a good whose price is $\mathrm{P}$, the income that the price-taking country ( $B$ in the model) gets per unit of that good is $P /(1+t)$. For the same good, the price-taker receives less income than the price-setter, though both countries might even use the same investment and labour in producing the good; the price-taker pays P.t/(1+t) in tariffs per unit of cloth as a tax to the price-setter's government, but pays the price-setter's prices for the goods it imports. If the export good of the price-taker is made from a primary product that the country could have exported or had to import, as with textiles made from cotton, the tariff reduces the income of the exporter disproportionately because the tariff is proportionate to the price of the good including the raw material. ${ }^{2}$ This, in brief, is the argument of unequal exchange.

The argument rests on the wage difference. Reverting to the model, A can lower the price B receives for its cloth because B's wage is lower. Were B's wage only a little below A's but the tariff high, B would not export; the greater the wage difference, the higher the tariff that A can impose without cutting off trade.

In the real world unequal exchange is a broader phenomenon, it also occurs when low wage countries export goods that high wage countries do not produce, i.e. certain primary products. Examples are coffee, tea, cocoa, bananas, jute and many spices and flavours. These goods would cost more to produce if the workers who produced them were to be paid the wages of the developed countries, even if the most mechanised techniques were used. The income the producer receives per unit of output is determined by the wage rate; because its wage rate is low the developing country receives less income per unit of output than it would if the wage rate were high.

The argument that developing countries receive less income per unit of output than do developed countries because they pay lower wages was

\footnotetext{
${ }^{2}$ Taking $\mathrm{C}$ as the cost of the cotton in the cloth (and neglecting other current inputs), the value added, hence the income, from producing cloth in the price-setting country is $\mathrm{P}-\mathrm{C}$, whereas the price-taker receives $\mathrm{P} /(1+\mathrm{t})-\mathrm{C}$. The price-setter need only raise $t$ to $(\mathrm{P}-\mathrm{C}) / \mathrm{C}$ to eliminate the price-taker's income; for instance, if the value added is $20 \%$ of the pricesetter's price of the good, with a tariff of $25 \%$.
} 
first put forward by Arghiri Emmanuel in 1969. ${ }^{3}$ His formal reasoning rested on an unsound Marxist labour theory of value in international trade and has, therefore, been easy to dispute. For example, Krugman and Obstfeld purport to refute Emmanuel by presenting unequal exchange as meaning simply that the labour used directly in the production of exports of developing countries is greater than the labour used directly in the production of the goods they import in exchange from the developing countries. They state, "In asking whether trade is beneficial, you should not compare the domestic labour used to produce your exports with the foreign labour used to produce your imports. Rather, you should compare the labour used to produce your exports with the amount of labour it would have taken to produce your imports yourself. If another country can produce your imports with much less labour than would have been required in your country, good for them; this fact does not reduce your own benefit from trade."

Nonetheless, Emmanuel's point is obvious; it is a point about income, not about the quantities of labour exchanged. And, once again, the neo-classical theory's manner of representing trade precludes a phenomenon that evidently must occur.

Unequal exchange can, in principle, be quantified for the goods that compete with the goods produced by the developed countries merely by finding the unit values and the volumes exported by the developing countries. If the sole cause of the difference between the price-setter's and price-taker's prices for a particular good is a tariff, as opposed to quotas and other trade barriers, an even simpler, direct measure is the developed countries' tariff revenues from the imports of that good. The effect of trade restrictions on the income Pakistan derived from its cotton textile exports in the 1960s was mentioned earlier. Since cotton textiles were Pakistan's principal exports at the time, along with jute products, which earned no better, the income Pakistan lost from unequal exchange must have been many times greater than the foreign aid it received. Since then developed countries have placed more reliance on import quotas and have allowed the developing countries some freedom in administering them themselves so as to reduce the extent to which their own exporters bid down their prices. But no terms of trade effect appears to have followed and, consequently, the same unequal exchange continues.

In a case like Pakistan's textiles, unequal exchange is a natural phenomenon; Pakistan is trying to sell a good the buying country can supply

\footnotetext{
${ }^{3}$ Originally published in French as 'L'Echange Inégal', François Maspero, Paris. 1969.

${ }^{4}$ Krugman and Obstfeld. p. 22
} 
itself and, therefore, does not want to buy. The 'arrangements' by which the developed countries restricted textile imports merely reflect this. Reverting to the model of this article, country A does not gain from free trade if B's cloth is sold at A's price, but it loses if the price of the cloth is lower and rapid growth of import causes unemployment. By imposing a tariff and extracting revenue from $\mathrm{B}, \mathrm{A}$ does gain from trade. When economists advise countries whose exports are hampered by trade barriers of the importing countries to try harder, they ignore the elementary rule that a seller whose wares are not wanted gets a bad price.

When a primary product of a low wage country does not compete with a product of a high wage country, the constraint on raising the price (assuming that the producers co-operate) is that demand may be elastic. Developing countries often have to accept lower prices to increase their foreign exchange earnings. Here, the obvious remedy is to move into activities that offer more income, preferably into manufacturing goods that can be sold at the prices of the developed countries. To the extent that the new activities are subject to the trade barriers of the developed countries, they continue to suffer unequal exchange. But, to the extent that low wage countries can supply each other with capital and consumer goods at their own prices, unequal exchange can be avoided.

\section{World prices}

According to orthodox economic theory, free competitive international trade ensures that the price of any tradable good will be the same in all markets. The theory concludes from this that all tradable goods that are produced have world prices. For most developing countries this means that, since they can not influence world prices, the 'small country assumption', they reach an optimal allocation of resources by adopting them. But any traveller knows that prices differ from country to country, even among developed countries, and, as discussed in the first part of the present article, the studies carried out by economists confirm what the traveller knew already.

Even if prices of goods were the same in all countries, it would not follow that all tradable goods that are produced have world prices. An example of such an exception occurs in the model when the highest rate of return that the low wage country, $B$, obtains in free trade comes from importing $\mathrm{k}_{\mathrm{y}}$-machines, using them to make $\mathrm{b}_{\mathrm{z}}$-machines and using these to make cloth. (See section D, equations 6 and 7.) In this case $a b_{z}$-machine has no world price because it can not be trade. It can not be exported to the high wage country, A, because its output is too low to be competitive at A's high wage and it costs more to make in $A$ than in $B$. Yet, this $b_{z}-$ 
machine is produced, because it yields the highest rates of return to $B$, and is tradable. It is not traded at the prevailing prices, but might be if prices were different. A proof that this is possible is easily provided by a diagram.

But the differences in the prices of the same goods in different countries probably imply that the failure of orthodox international trade theory is greater than argued so far in the present article. For it shows that the larger economies, at least, have their own price structures and that trade does not lead to equalisation of prices. A rough illustration can be given by taking two fully integrated developed economies in isolation. Production in the one is represented by a simple input:output matrix, S, and in the other by a similar matrix, $T$. The nominal wage in the first is $W_{1}$ and in the second $W_{2}$, and $R_{1}$ and $R_{2}$ are the rates of profit. Then the prices are given by:

$$
\mathrm{P}_{1}=\mathrm{W}_{1}+\mathrm{S} . \mathrm{P}_{1} \text { and } \mathrm{P}_{2}=\mathrm{W}_{2}+\mathrm{S} . \mathrm{P}_{2} \text {. }
$$

According to orthodox theory, free trade will ensure that one country does not produce certain goods and the other country does not produce certain others. Behind this conclusion is the standard argument that competition will prevent the same good from being sold at different prices in the two countries. In reality, what seems to happen is that the countries keep their prices and their production structures largely intact, i.e. $\mathrm{P}_{1}$ and $\mathrm{P}_{2}$ do not change with trade, but the exporting industries in each country accept that prices and rates of return they get from exporting will be different to those they get at home, and that the relationship between the export price and the rate of return is determined by the exchange rate. (It may be absurd to compare two countries before and after trade is opened, but, since it is the standard method for expounding orthodox theory and concluding that there are gains from trade, it can be allowed for the rough explanation given here.) 


\section{References}

Baldwin, Robert, 1971, "Determinants of the Commodity Structure of U.S. Trade." American Economic Review.

Becker, Gary. "Human Capital and the Personal Distribution of Income" W.S. Woytinski Lecture No.1. University of Michigan.

Chipman, John S. "A Survey of the Theory of International Trade: Part 3, The Modern Theory." Econometrica. 1966.

Dornbusch, Rudiger. "Purchasing Power Parity" National Bureau of Economic Research No. 1591. 1985.

Haberler, Gottfried v., 1937, The Theory of International Trade with its Applications to Commercial Policy Translated from the German. MacMillan. New York.

Helpman, Elhanan, and Paul R. Krugman. "Market Structure and Foreign Trade. Increasing Returns, Imperfect Competition, and the International Economy.” MIT. 1985.

Isard, Peter. "How Far Can We Push the Law of One Price?" American Economic Review, 1977.

Isard, Peter. (2) 1995 ,Exchange Rate Economics Cambridge University Press.

Krugman, Paul R., and Maurice Obstfeld, 1994, International Economics: Theory and Policy. Harper Collins, New York. Third edition.

Krugman, Paul. "Pricing to Market when the Exchange Rate Changes" National Bureau of Economic Research No. 1926, 1986.

Krugman, Paul. (2), 1989, Exchange Rate Instability MIT Press.

Leontief, Wassily. "Domestic Production and Foreign Trade: The American Capital Position re-examined." Proceedings of the American Philosophical Society 97. 1953.

Marston, R. "Pricing to Market in Japanese Manufacturing" Journal of International Economics, 1990.

Meade, James Edward, 1955, The Theory of International Economic Policy. Vol. II. Trade and Welfare. Oxford University Press. 
174 The Lahore Journal of Economics, Vol.4, No.2

Rodrik, Dani. "What Does the Political Economy Literature on trade Policy (not) Tell us that we ought to know?" National Bureau of Economic Research Paper No. 4870. U.S. Centre for Economic Policy Research Discussion Paper No. 1039, U.K. 1994.

Samuelson, Paul A. "International Trade and the Equalisation of Factor Prices” Economic Journal, 1948.

Serven, Luis, and Solimano, Andres "Adjustment Policies and Investment Performance in Developing Countries: Theory, Country Experience, and Policy Implications" Working Paper No. 606. Policy, Research, and External Affairs. Country Economics Department. World Bank, 1991.

Vanek, Jaroslav, 1968, "The Factor Proportions Theory: the N-Factor Case" Kyklos.

Yang, Jiawan. "Pricing-to-Market in US Imports and Exports: a Time Series and Cross-Section Study" The Quarterly Journal of Economics and Finance, 1988. 